\title{
NIHRAC approves 11 gene-therapy protocols
}

The 11 WASHINGTON, D.C.-Participants at last month's meeting of the National Institutes of Health Recombinant DNA Advisory Committee (NIHRAC, Bethesda, MD) received a 24-centimeter stack containing more than 4,500 pages of documents. In sifting through this voluminous material, committee members approved 11 procedures involving human gene transfers, including 6 involving cancers, 3 focused on genetic diseases, and 2 for individuals infected with HIV.

One of the protocols for HIV patients was submitted by Viagene (San Diego, CA). The approachwhich represents a refinement of an investigational-new-drug application that the Food and Drug Administration (FDA, Bethesda, MD) approved last year-entails transferring modified HIV-envelope genes into $\mathrm{T}$ cells from HIV-infected patients. The engineered $\mathrm{T}$ cellswith fragments of HIV envelop proteins present in them-are then reintroduced into the patients. Viagene believes that this approach will provoke both a humoral immune response and a cell-mediated immune response against HIV.

Because the Viagene protocol receives no federal support, there is "no necessity" for it to come before NIHRAC, according to Nelson Wivel, director of the NIH Office of Recombinant DNA Activities. However, says Wivel, NIHRAC often has "looked at matters for biotechnology companies, even before the days of gene therapy."

Nonetheless, several committee members were uneasy at the prospect of renewing this practice by evaluating Viagene's proposal, particularly because some details of the proposal were designated "proprietary" and thus were not supplied to the committee. "This gets curiouser and curiouser," says NIHRAC's Alex Capron of the University of California at Los Angeles. "If Viagene officials are looking for our "Good Housekeeping Seal,' don't they have to turn in all their Tupperware? Companies should be prepared to give us the same information as other researchers give us. Let's not set up a dual track for review."

Despite such misgivings, the ma- jority of NIHRAC agreed to conduct the review. "We should encourage companies to come before us," asserts Dusty Miller of the Fred Hutchinson Cancer Research Center (Seattle, WA). "If they don't, that raises questions." Another member of the committee, Robert Haselkorn of the University of Chicago (Chicago, IL), even suggestsalbeit facetiously - that companies coming before NIHRAC should pay a fee. He argues that the approvals they receive boost stock values and otherwise serve corporate interests. In the face of FDA user fees, his suggestion is perhaps not so whimsical as Haselkorn portrays it.

According to Steven Mento, Viagene's vice president for research and development, part of the reason for bringing the protocol before NIHRAC is that some of the protocol's clinical testing may be conducted at NIH-supported clinical centers. Indeed, Viagene researchers already are collaborating with scientists at UCLA and the University of Southern California (Los Angeles, CA). Since both institutions receive federal funding, they are formally bound by NIHRAC policies.

After Viagene officials promised to provide withheld information to the committee on a confidential basis, NIHRAC members voted without opposition to approve the company's protocol. Subsequently, the committee also approved a second HIV-related proposal from Gary Nabel of the University of Michigan Medical Center (Ann Arbor, MI). Taking a different approach, Nabel and his colleagues plan to transfer a mutant form of the HIV rev gene into the T cells of AIDS patients. The resulting mutant rev protein would then inhibit replication of HIV if the virus infects the T cells, Nabel believes.

One of the protocols for treating malignancy that NIHRAC recommended for approval is particularly noteworthy. Outlined by Joseph Ilan of the Case Western Reserve University School of Medicine (Cleveland, $\mathrm{OH}$ ), the protocol involves the use of antisense DNA molecules to block brain tumors. Specifically, the Ohio team plans to transfer an antisense gene for insulin-like growth factor-1 (IGF-1) into tumor cells from patients, irradiate those cells, and then reintroduce them into the patients. Tumor cells over produce IGF-1, so inhibiting its synthesis may interfere with tumor cell growth, Ilan explains. Irradiation, for its part, prevents tumor cells from replicating but does not immediately prevent them from producing proteins.

Although members of NIHRAC commended Ilan's "innovative approach" and recommended its approval, they criticized his proposal and several other proposals, because crucial data were missing from materials presented to the committee. In fact, NIHRAC deferred several proposals because of a lack of critical data. However, in several cases, including Ilan's, the committee recommended approval, contingent on data being supplied before final recommendations are sent onward to the NIH director. The committee members thus renewed their long-standing debate over their inconsistency, though the issue remains unresolved.

Another policy issue - how to deal fairly with expedited reviews, particularly of "compassionate use" requests for gene-therapy protocols-also continues to perturb committee members. Late last year, NIH director Bernadine Healy overruled NIHRAC and approved a special request to use an unproved genetherapy approach on a San Diego woman with an inoperable brain tumor. Healy then asked the committee to develop procedures for reviewing gene-transfer proposals on an expedited basis.

Yet many committee members do not want politics dictating "preferential treatment" for certain patients, says NIHRAC's Gary Chase of the Johns Hopkins University (Baltimore, MD). Moreover, he and others say that all protocols should receive even-handed public review from the committee. The committee still has not had a chance to do that for the protocol that Ivor Royston and his colleagues at the San Diego Regional Cancer Center (San Diego, CA) developed to treat their patient with the inoperable brain tumor, Chase notes.

-Jeffrey L. Fox 